\title{
Article
}

\section{Uncovering Scientist Stereotypes and Their Relationships with Student Race and Student Success in a Diverse, Community College Setting}

\author{
Jeffrey Schinske, Monica Cardenas, and Jahana Kaliangara
}

\author{
Biology Department, De Anza College, Cupertino, CA 95014 \\ Submitted December 18, 2014; Revised May 30, 2015; Accepted June 1, 2015 \\ Monitoring Editor: Jose Herrera
}

\begin{abstract}
A number of studies have identified correlations between children's stereotypes of scientists, their science identities, and interest or persistence in science, technology, engineering, and mathematics. Yet relatively few studies have examined scientist stereotypes among college students, and the literature regarding these issues in predominantly nonwhite and 2-yr college settings is especially sparse. We piloted an easy-to-analyze qualitative survey of scientist stereotypes in a biology class at a diverse, 2-yr, Asian American and Native American Pacific Islander-Serving Institution. We examined the reliability and validity of the survey, and characterized students' comments with reference to previous research on stereotypes. Positive scientist stereotypes were relatively common in our sample, and negative stereotypes were rare. Negative stereotypes appeared to be concentrated within certain demographic groups. We found that students identifying nonstereotypical images of scientists at the start of class had higher rates of success in the course than their counterparts. Finally, evidence suggested many students lacked knowledge of actual scientists, such that they had few real-world reference points to inform their stereotypes of scientists. This study augments the scant literature regarding scientist stereotypes in diverse college settings and provides insights for future efforts to address stereotype threat and science identity.
\end{abstract}

\section{INTRODUCTION}

\section{Do Scientist Stereotypes Still Deserve the Attention of Researchers in the 21st Century?}

Given that, extending back at least as far as the 1950s, researchers have studied the ways students view scientists, one might reasonably ask whether there is anything left to learn about scientist stereotypes in the present day. Indeed, almost anyone could probably describe a relatively

CBE Life Sci Educ September 2, 2015 14:ar35

DOI:10.1187/cbe.14-12-0231

Address correspondence to: Jeffrey Schinske (schinskejeff@deanza .edu).

(C) 2015 J. Schinske et al. CBE-Life Sciences Education (c) 2015 The American Society for Cell Biology. This article is distributed by The American Society for Cell Biology under license from the author(s). It is available to the public under an Attribution-Noncommercial-Share Alike 3.0 Unported Creative Commons License (http://creativecommons.org/licenses/by-nc-sa/3.0).

“ASCB®" and "The American Society for Cell Biology ${ }^{\circledR}$ " are registered trademarks of The American Society for Cell Biology. consistent version of a "stereotypical scientist" (likely including the wild hair, lab coat, socially awkward demeanor, and other common stereotypes). However, despite the wealth of existing information available on scientist stereotypes from a variety of sources, we argue that further study is warranted in this area for two critical reasons. 1) Strikingly, nearly every prior study of scientist stereotypes was conducted among predominantly white populations of $\mathrm{K}-12$ students. Because cultural factors have the potential to shape an individual's stereotypes (Hamilton and Sherman, 1994), it is surprising to find so little evidence describing the most common stereotypes among students of color or among college students more generally. 2) As science educators focus more intently on how student success is impacted by affective elements of classrooms (Trujillo and Tanner, 2014), including issues of student identity and stereotype threat, understanding the present-day perceptions of scientists among students becomes a crucial starting place for building awareness and crafting interventions. As one recent paper summarized, "Despite the potential value of stereotypes to understanding ... underrepresentation in science, there is a dearth of empirical research to document 
current college students' stereotypes of scientists in detail" (Wyer et al., 2010, p. 388).

\section{A Brief History of the Research on Stereotypes of Scientists}

Finson (2002) and Schneider (2010) provide extensive reviews of the history of measuring stereotypes of scientists. Rather than replicating those authors' reviews, the following represents a summary of this history with an emphasis on work done at the college level.

One of the first and most influential studies of scientist stereotypes involved the analysis of essays regarding perceptions of scientists from $~ 35,000$ high school students (Mead and Metraux, 1957). The researchers generated long lists of observed stereotypes and categorized the stereotypes as either "positive" (e.g., intelligent, highly trained, devoted) or "negative" (e.g., brainy, dull, work alone). Beardslee and O'Dowd (1961) published the first account of scientist stereotypes among college students after conducting unstructured interviews with undergraduates, uncovering results mirroring those of Mead and Metraux (1957). Dikmenli (2010) also conducted a qualitative survey of stereotypes among undergraduates using a free word-association test regarding science and scientists. Words associated with "scientist" included, as before, both negative and positive descriptions, and fit into six categories: personal characteristics, activities, names of scientists, workplaces, technological developments, and physical characteristics (Dikmenli, 2010).

These efforts, particularly those of Mead and Metraux (1957), resulted in the development of various multiple-choice surveys to assess scientist stereotypes. Such surveys included the Images of Science and Scientists Scale (ISSS; Krajkovich and Smith, 1982), the Women in Science Scale (Erb and Smith, 1984), and the Stereotypes of Scientists Scale (SOS; Wyer et al., 2010). These quantitative surveys have occasionally been deployed in college settings (e.g., Schneider, 2010; Guy, 2013).

While such quantitative surveys have the advantages of being generalizable, easy to analyze, and helpful for testing specific hypotheses, they limit the range of possible responses for participants and may fail to detect important themes or contextual meanings (Frechtling, 2002). These issues might be of particular concern for the ISSS (Krajkovich and Smith, 1982) and SOS (Wyer et al., 2010), which despite being published fairly recently were based in large part on the stereotypes set forth in qualitative data published in the 1950s. Qualitative surveys could therefore help to explore the breadth of student ideas regarding stereotypes and identify unanticipated responses that might be lacking in the more commonly used quantitative surveys (Bickman and Rog, 2009, p. 221).

Perhaps the most widely used qualitative survey to date, the Draw-A-Scientist Test (DAST), was introduced by Chambers (1983) to examine scientist stereotypes among young children. In the DAST, participants are asked to "draw a picture of a scientist." Drawings are then evaluated with reference to a selection of stereotypes from Mead and Metraux (1957). Though the DAST has been most commonly used with young children, it has also been administered in college environments. Such studies have helped compare undergraduates' stereotypes of scientists between science and non-science majors (Rosenthal, 1993), between Hebrew-speaking and Arabic-speaking preservice teachers (Rubin et al., 2003), and between women and men (Thomas et al., 2006). The DAST has additionally been used as a metacognitive tool to assist in shifting stereotypes held by undergraduates (Miele, 2014).

Though the DAST is a simple tool that has been used across contexts and over long periods of time, many researchers have raised concerns regarding potential weaknesses inherent in the test (Schneider, 2010). Experimenter bias in interpreting drawings and even the gender of the person administering the test can influence results (Sumrall, 1995; Thomas et al., 2006). Many drawings appear to be based on a self-image, and the materials provided to participants or participants' artistic abilities can strongly influence results (Sumrall, 1995). Symington and Spurling (1990) and Thomas et al. (2006), therefore, questioned whether the DAST captures an accurate view of how individuals view scientists. As such, additional qualitative studies beyond DAST would assist in corroborating prior work and guiding the development of interventions regarding stereotypes.

\section{Can Scientist Stereotypes Influence Persistence and Success in Science?}

Multiple lines of evidence suggest that the attitudes students develop regarding science and scientific careers are important factors in predicting persistence and success in science, technology, engineering, and math (STEM; Weinburgh, 1995; Tai et al., 2006; Trujillo and Tanner, 2014). In one of the largest studies to examine the issue, Seymour and Hewitt (1997) found that "what distinguished the survivors [in STEM] from those who left was the development of particular attitudes or coping strategies" (p. 30). Such attitudes are, at least in part, shaped by issues surrounding stereotypes and identity (Trujillo and Tanner, 2014). A stereotype is commonly defined as "a widely held but fixed and oversimplified image or idea of a particular type of person or thing" (Oxford English Dictionary, 2014). Gee (2000, p. 99) theorized that identity involves recognizing oneself as a "certain "kind of person' or even as several different 'kinds' at once." Because stereotypes are one way of describing a "type of person," stereotypes may be an important means of constructing identity, and an important factor in the development of attitudes and strategies for success in STEM.

Several studies have examined the ways stereotypes and the construction of identities relate to success in STEM. One overarching trend indicates students are more likely to pursue majors and careers in STEM if they agree with certain "positive" stereotypes of scientists (Beardslee and O'Dowd, 1961; Wyer, 2003; Schneider, 2010). This suggests a clear relationship between positive stereotypes and choice of majors / careers. However, because these studies relied largely on quantitative surveys developed using stereotypes in Mead and Metraux (1957), they may have failed to detect trends in persistence related to more modern descriptions of scientists. In addition, the participants in these studies did not provide information to indicate whether they felt the stereotypes accurately described themselves as well as the scientists. Therefore, even if these students held "positive" views of scientists, they might not personally identify with those stereotypes or find them relevant to their career choices. 
Students who consider people like themselves to be different from scientists might fear being reduced to the stereotypes of their own group; that is, not good at or not belonging in science. This phenomenon, stereotype threat, has the potential to hamper engagement and performance in classes (Steele, 1997).

Recent studies have found evidence of such conflicts between scientist stereotypes and identities that appear to hinder performance in STEM classes. Brickhouse et al. (2000) and Carlone (2004) suggested that when students view scientists as having substantially different qualities compared with themselves or compared with the qualities valued in their home communities, the students were more likely to resist the development of a science identity and disengage from science. Ryder-Burge (2011) further demonstrated that, for females but not for males, chances of majoring in a STEM field increased when students' identities matched their perceptions of scientist identities (Ryder-Burge, 2011). Guy (2013) elaborated on this work by providing parallel surveys of self and scientist identity to black male undergraduates. Greater similarities between self and scientist identities correlated with greater likelihood of intending to persist in STEM. This relationship was particularly strong for black men identified as "low-performing" students (Guy, 2013).

In summary, the educational research literature includes numerous lines of evidence suggesting that agreeing with certain stereotypes of scientists has the potential to influence interest, persistence, and performance in STEM. Efforts to better understand scientist stereotypes and science identity among undergraduates could therefore inform future interventions and curricular changes to enhance student success in STEM.

\section{Why Is It Especially Important to Understand Stereotypes in Diverse, Community College Environments?}

Nearly all of the previous studies describing stereotypes of scientists appear to have been conducted in classrooms composed predominantly of white students. However, stereotypes are influenced by cultural factors (Hamilton and Sherman, 1994) and may therefore differ among students of different races. In addition, students from underserved groups frequently lack scientist role models from their groups (Dix, 1987; Sax, 2001), making it less likely that they would have concrete examples to shape their views of scientists. For these reasons, it is unclear whether scientist stereotypes observed among mostly white students will apply in mostly nonwhite classrooms. Indeed, a few studies have detected differences in the images of science and scientists among different demographic groups (Chambers, 1983; Catsambis, 1995; Rubin et al., 2003). As a number of nationwide efforts seek to address the shortfall in scientists from black, Latino/a, Native American, and certain Asian and Pacific Islander (AAPI) backgrounds (Astin and Astin, 1992; National Academy of Sciences, National Academy of Engineering, and Institute of Medicine, 2011; Maramba, 2013), an understanding of scientist stereotypes among students of color could prove valuable.

Perhaps most notably, we did not encounter in our literature search any previous studies that examined scientist stereotypes in community college settings. Because nearly half of all undergraduates nationwide are attending community colleges and because the majority of Latino/a, Native American, AAPI, and approximately half of black undergraduates are attending community colleges (American Association of Community Colleges, 2014), these colleges play a particularly critical role in efforts to recruit and retain traditionally underserved students in science fields. Hence, the need for additional evidence regarding students' views of science and scientists is perhaps especially pressing in community colleges.

\section{Goals and Scope of This Study}

The current study seeks to address the above-described gaps in the literature by: 1) piloting a survey of scientist stereotypes in a mostly nonwhite community college setting; 2) employing a survey using written and spoken responses, rather than a multiple-choice survey or drawings; 3) performing quantitative analyses to search for correlations between scientist stereotypes, student demographic characteristics, and success rates in a science course; and 4) comparing Mead and Metraux's (1957) scientist stereotypes with those identified by present-day students.

\section{METHODS}

\section{Study Location and Class Context}

De Anza College is one of the largest single-campus community colleges in the United States, serving $\sim 22,000$ students each quarter. The majority (59\%) of De Anza's Spring 2014 students came from low socioeconomic status families, and $31 \%$ of Spring students were first-generation college students. The majority of enrolled students (66.2\%) indicated the educational goal of transferring to a 4-yr institution. De Anza is a designated Asian American and Native American Pacific Islander-Serving Institution (AANAPISI).

All work for this study was conducted in the 2012-2013 and 2013-2014 academic years in a general education biology course titled Human Biology. Human Biology is a one-quarter overview course open to any student but targeting transfer students and those with interests in human health careers. Only $\sim 20 \%$ of Human Biology students state the intention of majoring in biology. Forty-one percent of Human Biology students report that Human Biology is the first college science class they have taken, and $13 \%$ of students report that Human Biology is the first science class they have ever taken at any level. The same instructor (J.S.) taught all of the Human Biology sections involved in this study.

\section{Collection of Demographic Information}

Each quarter, in the week before the start of classes, the instructor sent an email to all students registered in his Human Biology classes, asking them to complete an online survey. The final page of the survey asked students to identify their gender identities, racial identities, and first spoken language. Students received five participation points (out of 865 course points) for completing the survey by the end of the first week of class.

\section{Development and Deployment of the Qualitative Survey}

With the goal of collecting qualitative data from community college students regarding the types of people they think 
do science, constructed-response questions were developed and piloted in Human Biology classes during the 2012-2013 academic year. Face validity was established by adjusting question wording until at least $85 \%$ of students responded by describing one or more specific characteristics of scientists. The final constructed-response question read, "Based on what you know now, describe the types of people that do science. If possible, refer to specific scientists and what they tell you about the types of people that do science." This prompt was chosen in part to connect this survey with concepts of identity as expressed by Gee (2000). In addition, we selected this format with the goal of eliciting the most prominent characteristics of scientists relevant to students at the time they completed the survey, without restricting students to certain preselected characteristics or forcing students to record a certain number of characteristics. Finally, this prompt encouraged students to name specific scientists when describing the characteristics of scientists, in anticipation that this would help interpret students' thoughts. We experimented with surveys in which separate prompts asked students to describe scientist characteristics versus scientist names, but we found that combining the instructions into a single prompt stimulated richer responses than the sum of two separate prompts.

During the second Human Biology lecture meetings of Fall 2013 and Spring 2014, students were provided with the above constructed-response question on a piece of paper. The instructor introduced the activity and explained his interest in better understanding what students think about science. The paper included the instructions, "Please respond to the following question to the best of your ability. There are no 'right' or 'wrong' answers. You will receive participation points for providing complete responses, but your answers will not be graded." The instructor reiterated that he valued students' candid responses and that the only "correct" answer was one that genuinely reflected a student's own ideas. Students were told they would have $\sim 10 \mathrm{~min}$ to respond, and if they finished writing, they could think quietly and add any new thoughts that arose during that time. All surveys were completed on paper (not electronically).

For investigation of test-retest reliability, Spring 2014 students responded to the same prompt again during the seventh week of class. No specific instruction or activities regarding the types of people who do science took place between weeks 1 and 7 of class. The instructor used the same instructions in facilitating the week 7 survey as in week 1 , but added that students would no doubt recognize the prompt from earlier in the class and that he had no particular expectations regarding whether students ideas had stayed the same or changed, and they therefore did not need to worry about making their responses similar to or different from previous responses.

During Summer 2014, we conducted systematic follow-up telephone conversations with a subset of Fall 2013 and Spring 2014 students regarding their survey responses. These one-on-one discussions served as an opportunity to validate our interpretations of student comments and better understand how students thought about the prompts as they wrote. In each phone conversation, we read from the student's responses to the survey and asked the student to say a few more words about each of her/his comments. We further asked each student what she/he was thinking about when writing to the prompt and whether she/he recalled drawing on any particular experiences or memories when responding to the prompt. If the student was part of the class that took the survey multiple times, we asked what it was like to take the survey again, whether the student felt like she/he remembered her/his responses from the first survey during the second survey, and whether the student remembered feeling particularly motivated to write similar or different points when taking the survey a second time.

\section{Analysis of Qualitative Survey Responses}

All student papers were anonymized by removing student names and were labeled with a random number. We transcribed each student comment into a different column of a spreadsheet and tallied the number of times each comment appeared among students' papers. Because most recent studies regarding scientist stereotypes have been based on Mead and Metraux's (1957) qualitative survey, we used the stereotypes in that paper as the point of comparison for our data. This in part allowed us to assess the present-day relevance of the 1950s scientist stereotypes, which have formed the basis of most recent quantitative surveys of scientist stereotypes. Because our prompt also elicited names of scientists, we used the list of names from Dikmenli (2010) to determine whether scientists named in our data corresponded to previously identified stereotypical scientists. We therefore coded comments into two main categories. Stereotypes (subcategories: Positive Stereotypes, Negative Stereotypes, Stereotypical Scientists) included descriptions directly referenced in Mead and Metraux (1957) and scientists referenced in Dikmenli (2010). Nonstereotypes (subcategories: Nonstereotype Descriptions, Nonstereotypical Scientists) included descriptions or names of scientists not directly referenced in those papers. As we coded student comments, it became apparent that many students had listed types of science or fields of science in their responses (e.g., "biology" or "chemist"), which did not fit well into any of the above categories. Therefore, an additional category was created for Fields of Science (Figure 1).

We initially worked collaboratively coding the same set of five papers until agreement was reached on appropriate codes. Thereafter, we worked independently in analyzing student responses. In calculating interrater reliability, we independently analyzed 20 of the same papers. Because the data were continuous (number of Stereotype and Nonstereotype comments per student), the Pearson correlation coefficient was calculated to determine whether we reliably recorded the same number of Stereotypes and Nonstereotypes in those papers.

In calculating test-retest reliability, papers for students who did not take both the week 1 and week 7 surveys were excluded. Test-retest reliability was then calculated in two ways. First, the Pearson correlation coefficient was calculated to evaluate the level of correlation between each student's number of Stereotype and Nonstereotype comments during the first and seventh weeks of class. This provided evidence of whether or not students individually responded similarly at each time point. Second, Wilcoxon signed-rank tests were used to compare the number of Stereotype and Nonstereotype comments made by the class as a whole during the first and 

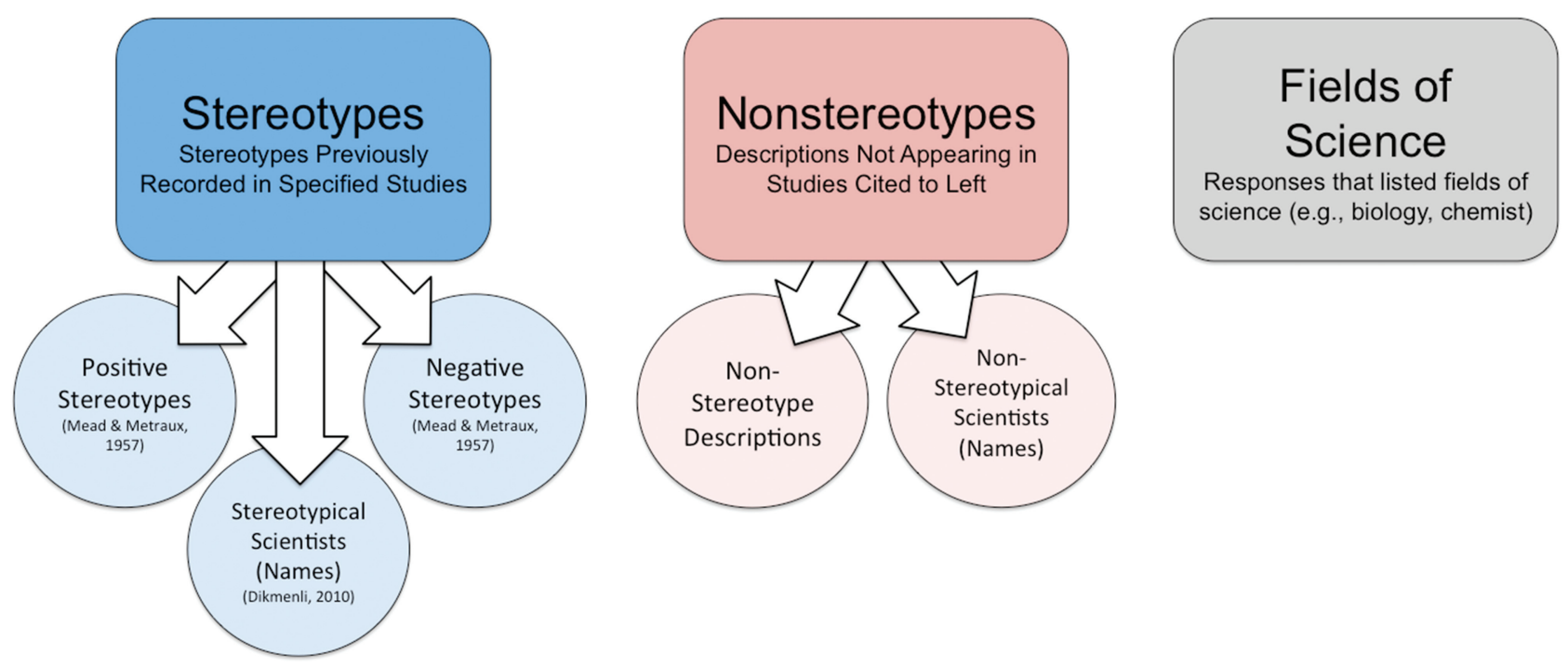

Figure 1. Categories and subcategories used in coding students' descriptions of scientists.

seventh weeks of class. This provided evidence of whether or not the population as a whole changed significantly over $6 \mathrm{wk}$ of class in the absence of explicit discussions of people who do science.

Mann-Whitney tests were used to search for differences in the numbers and types of comments made by students from different demographic groups. For additional analysis, continuous data (number of comments per student in each category) were converted to nominal data (whether or not each student made any comment in each category). Chisquare tests were used to compare nominal data between different demographic groups. Finally, students' course grades, expressed both as a number (" $\mathrm{A}$ " $=4$, " $\mathrm{B}$ " $=3$, etc.) and nominally as Pass versus $\mathrm{D} / \mathrm{F} / \mathrm{W}$ (grade of " $\mathrm{D}$ " / grade of " $\mathrm{F}$ "/withdrew), were included in analyses to explore correlations between survey responses and in-class achievement. Mann-Whitney tests were used to search for trends in achievement/grades, and chi-square tests were used to compare Pass and D/F/W rates between groups of students. All statistical analyses were performed in JMP version 11.0.0 (SAS Institute, Cary, NC).

\section{RESULTS}

\section{Survey Population}

One hundred twenty-five students responded to the survey prompt during week 1 of Human Biology (62 students in Fall 2013 and 63 students in Spring 2014). The surveyed population was $56 \%$ female and $44 \%$ male. Students identified 14 different languages first spoken, and only $31 \%$ of students spoke English as their first language (Table 1A). Table 1B describes the racial identities selected by students. Owing to the relatively low numbers of African-American, Native American, Filipino, Pacific Islander, Laotian, and Cambodian students, those students were included with Latino/a students as traditionally underserved students for demographic analyses. Together, these underserved students comprised $37 \%$ of the surveyed population. Asian students represented the most prevalent group at $43 \%$, and white students represented $20 \%$ of the sample.

Thirteen students, eight women and five men, participated in telephone conversations during Summer 2014. Two of these students identified as black, three identified as Asian, one identified as Filipina/Pacific Islander, three identified as Latino/a, and four identified as white. Eight of these 13 students spoke English as a first language.

\section{Interrater and Test-Retest Reliability}

For the 20 papers coded by multiple reviewers, we found a Pearson correlation coefficient of 0.86 for coding Stereotypes and 0.89 for coding Nonstereotypes, indicating acceptable interrater reliability. In Spring 2014, 48 students took both the week 1 and week 7 surveys. Pearson correlation coefficients between individual students' week 1 and week 7 papers were 0.13 for number of Stereotypes $(p=0.37)$ and 0.18 for number of Nonstereotypes $(p=0.23)$, indicating that students' week 1 survey responses did not generally correlate with their week 7 responses. Considering the open-ended nature of the prompt, this is not entirely surprising. While students were allowed enough time to write until everyone had finished, the prompt did not ask students to provide a certain number of sentences or examples. We viewed this as a strength, since it had the potential to allow for the observation of students' most salient thoughts regarding the types of people who do science, without requiring students to add additional language that might not resonate as strongly with them. Because of this, however, students were left to independently decide how much they wished to write on each day of class. We hypothesized that another explanation for this lack of correlation might have stemmed from students' mind-sets when taking the survey a second time. Perhaps, even though students were told there was no expectation regarding whether their ideas had changed or stayed the same, many students might have felt their ideas should 
Table 1. Languages first spoken (A) and racial identities (B) of survey participants

\begin{tabular}{lrc}
\hline & Percent $^{\mathrm{a}}$ & $n(125$ total $)$ \\
\hline A. Languages first spoken & & \\
English & 31 & 39 \\
Others $(n=13)$ & 53 & 66 \\
Spanish & 15 & 19 \\
Vietnamese & 10 & 13 \\
Chinese & 10 & 13 \\
Korean & 5 & 6 \\
Indonesian & 2 & 3 \\
Japanese & 2 & 3 \\
Tagalog & 2 & 3 \\
Assyrian & 1 & 1 \\
Hebrew & 1 & 1 \\
Lao & 1 & 1 \\
Punjabi & 1 & 1 \\
Romanian & 1 & 1 \\
Tigrinya & 1 & 1 \\
Unknown or decline to state & 16 & 20 \\
B. Races & & \\
Asian & 43 & 54 \\
Latino & 24 & 30 \\
White & 20 & 25 \\
Black & 6 & 8 \\
Filipino or Pacific Islander & 5 & 6 \\
Laotian or Cambodian & 1 & 1 \\
Native American & 1 & 10 \\
Unknown or decline to state & 8 & \\
\hline
\end{tabular}

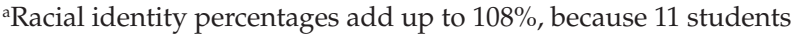
identified with two racial groups.

have changed and might have made a conscious effort to respond differently in week 7 . Some evidence from telephone conversations with students seemed to support this. Five of the nine students with whom we spoke from the Spring 2014 class clearly recalled making an effort to bring in new and different information when responding to the prompt in week 7 . For example, one student said she was "trying very hard to include new information" in week 7 , and another said she "tried to think of new things to write" each time.

Interestingly, despite the evidence that some students tried to write different types of things in week 7 compared with week 1 , the types of comments made by the class as a whole were quite similar between the two time points. Wilcoxon signed-rank tests indicated that the average number of Stereotypes recorded per student remained relatively constant (week $1=2.46[\mathrm{SD}=2.06]$, week $7=2.17[\mathrm{SD}=1.73], S=$ $-70, p=0.29)$, as did the average number of Nonstereotypes per student (week $1=0.67$ [SD $=0.93$ ], week $7=0.64$ [SD = $0.81], S=-12.5, p=0.79)$. This suggests that the survey exhibits test-retest reliability at the population level, and when considering a class as a whole, students do not significantly change their stereotypes of scientists simply as a result of spending seven weeks in a Human Biology class.

\section{Overview of Stereotypes Observed}

The 125 student papers included a total of 525 comments regarding the types of people who do science (average 4.2 comments per student [SD $=2.21]$ ), with responses ranging from one sentence to page-long essays. One hundred thirty-nine different descriptions of scientists were identified among the 525 comments (complete set in the Supplemental Materials). Tables 2-4 show the most common descriptions of scientists observed in each category along with the number of times each description appeared in student papers. Sample student quotes are provided to indicate the types of student statements that fell under each description. As described above and in Figure 1, we coded comments as either a Stereotype (subcategories: Positive Stereotypes, Negative Stereotypes, Stereotypical Scientists; Table 2), a Nonstereotype (subcategories: Nonstereotype Descriptions, Nonstereotypical Scientists; Table 3), or a Field of Science (Table 4).

Overall, Stereotypes previously identified in Mead and Metraux (1957) or Dikmenli (2010) made up 57\% of student comments, with one or more Stereotypes appearing in $97(78 \%)$ of the papers. Nonstereotypes made up $14 \%$ of student comments, with one or more Nonstereotypes appearing in $45(36 \%)$ of the papers. Fields of Science made up $29 \%$ of student comments, with one or more Fields of Science appearing in 44 papers (35\%). Positive Stereotypes represented, by far, the most prevalent subcategory. Forty-five percent of comments were Positive Stereotypes, which appeared in 91 (73\%) of the students' papers. Negative Stereotypes represented the least prevalent subcategory. Only $8.5 \%$ of comments were Negative Stereotypes, and Negative Stereotypes appeared in only 14 (11\%) of the papers. Six $(4 \%)$ of the most common scientist descriptions accounted for greater than $30 \%$ of all comments made by students. These six descriptions included five Positive Stereotypes ("curious," "interested in work," "intelligent," "works to make world better," "passionate") and one Stereotypical Scientist (Einstein).

\section{Validity of Coding Subcategories}

Evidence gathered during telephone conversations was used to examine whether the labels "positive" and "negative" were appropriate for describing the stereotypes placed in those categories by Mead and Metraux (1957). For example, it could be hypothesized that descriptions like "introverted" and "always indoors working in a lab" — negative stereotypes under Mead and Metraux (1957) — might carry positive connotations in regard to individuals with the ability to focus and work intensively. Three of the students we spoke with by phone had written one or more comments that were coded as Negative Stereotypes in their papers. In conversation, all three students appeared to verify that their comments were intended to have negative connotations. For example, one student wrote, "The types of people that do science are very introverted." This was grouped under the description of "asocial" and coded as a Negative Stereotype. In conversation, this student clarified, "Some scientists, I guess, they're you know, the stereotypical nerd. They sit in the corner. They don't really talk to anyone." Another student wrote, "People who do science work in a clean, white, and big building in which there's gas blowing and they where [sic] white clothes, gloves, and sometimes goggles." We coded this as a Negative Stereotype under the description of "always working in lab indoors." In conversation, this student explained, "I remember from some 
Table 2. Most prevalent student comments included in the Stereotypes category: Positive Stereotype (A), Negative Stereotype (B), and Stereotypical Scientist (C) subcategories, including their frequencies and representative student quotes ${ }^{a}$

\begin{tabular}{|c|c|c|}
\hline Description & $n$ & Representative student quotes \\
\hline \multicolumn{3}{|l|}{ A. Positive Sterotype } \\
\hline Curious & 42 & $\begin{array}{l}\text { "I believe people that do science are very curious and they want to understand the questions of the world." } \\
\text { "I think the type of people that do science are ones that enjoy striving for learning the unknown and have a } \\
\text { sense of curiosity." } \\
\text { "I think people that do science are very curious about the world." }\end{array}$ \\
\hline Interested in work & 31 & $\begin{array}{l}\text { "People who are interested in the subject and who enjoy researching new information." } \\
\text { "Scientist do science, or anyone that is interested in learning and gaining knowledge can do science." }\end{array}$ \\
\hline Intelligent & 25 & $\begin{array}{l}\text { "Scientist are very smart people and I think they have high IQs." } \\
\text { "[Scientists] are all smart people." }\end{array}$ \\
\hline $\begin{array}{l}\text { Works to make } \\
\text { world better }\end{array}$ & 19 & $\begin{array}{l}\text { "[Scientists] also usually have a desire to improve the human [and] world conditions to the best of their } \\
\text { abilities." } \\
\text { "The types of people that do science want to ... better the world." }\end{array}$ \\
\hline Passionate & 18 & $\begin{array}{l}\text { "The types of people who do science are those individuals who are passionate about knowing ... living things" } \\
\text { "Generally people that do science are ones who ... have a passion for discovery." } \\
\text { "I find most scientists are also passionate about their work." }\end{array}$ \\
\hline $\begin{array}{l}\text { Wish to discover } \\
\text { something }\end{array}$ & 13 & $\begin{array}{l}\text { "I see those who 'do' science are progressive and forward-thinking. They make new, revolutionary findings." } \\
\text { "There are people who become scientist[s] because they ... do it to help discover new things." }\end{array}$ \\
\hline $\begin{array}{l}\text { Do lab work/ } \\
\text { experiments }\end{array}$ & 11 & $\begin{array}{l}\text { "Scientist[s] are people who really like experiments." } \\
\text { "Experimenting with things allows them to figure stuff out." }\end{array}$ \\
\hline Dedicated & 10 & $\begin{array}{l}\text { "Also, the scientist has ... dedication." } \\
\text { "[Darwin] was interested and dedicated to what he was doing." } \\
\text { "People that do science for a living are often dedicated." }\end{array}$ \\
\hline Patient & 9 & $\begin{array}{l}\text { "The types of people that do science are patient." } \\
\text { "[Scientists] can, however, be anyone that has the patience and temperament for research and documentation." }\end{array}$ \\
\hline Innovative & 9 & $\begin{array}{l}\text { "I see those who 'do' science are progressive and forward-thinking. They make new, revolutionary findings that } \\
\text { could break away from traditional beliefs." } \\
\text { "The types of people that do science are innovative, observative [sic] people." }\end{array}$ \\
\hline Good at subject & 8 & $\begin{array}{l}\text { "People who are also good at science and excel in math tend to be scientist[s]." } \\
\text { "People that do science are smart people and really into science." }\end{array}$ \\
\hline $\begin{array}{l}\text { Other positive } \\
\text { stereotype } \\
\text { descriptions } \\
\text { cited by }<5 \% \text { of } \\
\text { respondents }\end{array}$ & 40 & $\begin{array}{l}\text { "[Scientists] like to focus on something." } \\
\text { "A scientist needs to wonder, needs to think ahead." } \\
\text { "Scientists often have a tendency to reject an idea until it becomes a pattern." }\end{array}$ \\
\hline \multicolumn{3}{|c|}{ B. Negative Stereotype } \\
\hline Asocial & 7 & $\begin{array}{l}\text { "The types of people that do science are very introverted." } \\
\text { "The types of people that do science are usually nerds." }\end{array}$ \\
\hline Mad/crazy & 5 & $\begin{array}{l}\text { "The types of people who do science are ... the crazy ones, hence the 'Mad Scientist.'" } \\
\text { "I heard that scientists are sometimes abnormal in the way they think ... all scientists are extreme." }\end{array}$ \\
\hline $\begin{array}{l}\text { Always reading } \\
\text { books }\end{array}$ & 3 & $\begin{array}{l}\text { "[Scientists] are always reading." } \\
\text { "The types of people that do science are always reading." }\end{array}$ \\
\hline $\begin{array}{l}\text { Always working in } \\
\text { lab/indoors }\end{array}$ & 3 & $\begin{array}{l}\text { "[Scientists] are always in their lab and do[ing] their experiments and taking notes while they're doing it." } \\
\text { "People who do science work in a clean, white, and big building in which there's gas blowing and they where } \\
\text { [sic] white clothes, gloves, and sometimes goggles." }\end{array}$ \\
\hline Strange/weird & 2 & $\begin{array}{l}\text { "Sometimes [scientists] can be seen in 'weird' people." } \\
\text { "For me, [scientists are] kinda strange." }\end{array}$ \\
\hline Boring & 1 & "The types of [people] who do science are the boring ones." \\
\hline $\begin{array}{l}\text { Overly involved in } \\
\text { work }\end{array}$ & 1 & "The types of people that do science ... obsess over their work." \\
\hline \multicolumn{3}{|c|}{ C. Stereotypical Scientist } \\
\hline Albert Einstein & 23 & $\begin{array}{l}\text { "For example, Einstein was a very curious person in physics." } \\
\text { "One scientist that comes to my mind is Albert Einstein." } \\
\text { "People who are also good at science and excel in math tend to be scientist[s], like Albert Einstein." }\end{array}$ \\
\hline Isaac Newton & 6 & $\begin{array}{l}\text { "Like Isaac Newton had to be curious so that he can observed [sic] gravity from a fallen apple." } \\
\text { "Newton is a good example. He established his three laws and founded calculus. He is the father of calculus." } \\
\text { "I know of Sir Isaac Newton who basically described to us the three laws of motion." }\end{array}$ \\
\hline Charles Darwin & 4 & $\begin{array}{l}\text { "Well, I guess the most scientist I'm familiar with is Darwin, and his studies on Natural Selection." } \\
\text { "Some scientist[s] I know of are Charles Darwin." }\end{array}$ \\
\hline
\end{tabular}


Table 2. Continued

\begin{tabular}{|c|c|c|}
\hline Description & $n$ & Representative student quotes \\
\hline Sigmund Freud & 4 & $\begin{array}{l}\text { "Sigmund Freud may have not had scientifically correct theories; he got a lot of people interested in the brain." } \\
\text { "A specific scientist is Sigmund Freud. Not all his theories were accepted by society but he enjoys challenging } \\
\text { things that he does not understand and see how they come to live." }\end{array}$ \\
\hline Thomas Edison & 2 & $\begin{array}{l}\text { "For example, the inventor of [the light bulb] Edison. He failed his experiment over a thousand time[s] but he } \\
\text { didn't give up." } \\
\text { "Einstein, Edison, Tesla, Freud. The types of [people] who do science want to satisfy their curiosity." }\end{array}$ \\
\hline Benjamin Franklin & 1 & "Next to some of the greatest like Benjamin Franklin." \\
\hline Leonardo da Vinci & 1 & "Some examples would be Leo Da Vince [sic]." \\
\hline Galileo Galilei & 1 & $\begin{array}{l}\text { "The only scientist I can think of at the moment is Galileo, the man that studied the stars and the Earth by using } \\
\text { science and proved the churches wrong." }\end{array}$ \\
\hline James Watson & 1 & "James Watson used the scientific method." \\
\hline
\end{tabular}

a Categories derived from those previously described in Mead and Metraux (1957) or Dikmenli (2010). See Introduction and Methods for details.

scenes in movies there's some mad scientists and there's many people wearing white clothes and wearing masks ... and they don't tell jokes. They're really serious about what they're doing." As such, written comments that were coded as Negative Stereotypes appear to have carried negative connotations for students.

Telephone conversations similarly appeared to confirm that comments coded as Positive Stereotypes were meant to convey positive characteristics. Twelve of the 13 students we talked to via phone had written one or more comments that were coded as Positive Stereotypes, and all appeared to view those comments as positive attributes. For example, one student wrote, "[Scientists] are patient and dedicated, because studies can take years or even decades to complete." This student clarified in conversation, "I was kind of amazed ... you hear of these people doing these studies or following these people for a few decades. ... It's awesome ... that someone is so passionate about a subject to stick with it for that long." Another student wrote, "I think the types of people that do science are forward thinkers that want to ... contribute to further development of knowledge." The student explained that this might be "like how a biologist would try to contribute to [better understanding of] heart problems." It therefore appears the terms "positive" and "negative" had similar meanings in the current study as in Mead and Metraux (1957). However, it remains likely that the exact extent to which any particular stereotype is seen as favorable or unfavorable is relative, and this area would benefit from further study.

\section{Evidence Regarding the Lack of Scientist Names in Responses}

Despite the fact that the prompt asked students to refer to specific scientists, only 41 students (33\%) named a specific scientist in their responses. Students who did not name a specific scientist were also more likely to name a Field of Science in their responses $(X=9.44, p=0.0021)$.

\section{Differences in Scientist Stereotypes among Demographic Groups}

Students identifying as white recorded, on average, more comments in their papers $(\bar{x} 5.6[\mathrm{SD}=2.21]$ comments per student) than did students from other races $(\bar{x} 4.0$ [SD $=2.19]$ comments per student, $Z=2.5, p=0.0123$; Figure 2A). We similarly observed a trend wherein students whose first language was English recorded a higher number of comments $(\bar{x} 4.7[\mathrm{SD}=2.31]$ comments per student) than students whose first language was not English $(\bar{x} 3.9$ [SD = 2.15] comments per student, $Z=1.82, p=0.068)$.

Considering the nominal data (whether or not each student recorded at least one comment in each category), there were no statistically significant differences between demographic groups in their likelihood of recording at least one Stereotype or Nonstereotype. At the level of subcategories, however, Asian students were more likely to record at least one Negative Stereotype than non-Asians. Ten percent of Asian students listed at least one Negative Stereotype, while only $1 \%$ of white students and $2 \%$ of traditionally underserved students did so $(X=8.59, p=0.0034)$.

To examine whether these trends were reflected in the number of comments from different categories in students' papers, it became necessary to first transform the data into percentages (percent of Positive Stereotypes out of all comments, percent of Nonstereotypes out of all comments, etc.). This helped control for the fact that nonwhite students, and to some extent language learners and men, recorded fewer total comments than their counterparts. Mirroring the signal in the nominal data, Asian students recorded Negative Stereotypes in an average of $9 \%$ of their comments $(S D=20.12)$, whereas non-Asian students mentioned Negative Stereotypes in only an average of $1 \%$ of their comments $(S D=6.31, Z=$ 2.93, $p=0.0034$; Figure 2B). Positive Stereotypes and Nonstereotypes appeared in similar frequencies among demographic groups (Figure 2, C and D).

Other demographic differences included that 23\% of women but only $10 \%$ of men used at least one Field of Science in their responses $(X=5.89, p=0.0152)$. Finally, men more frequently recorded the name of at least one Nonstereotypical Scientist than did women $(10 \%$ vs. $3 \%, X=8.59$, $p=0.0034)$.

\section{Stereotypes and Course Grades}

Course grades were based on 865 total points, which included two exams worth a combined 240 points, lecture active-learning exercises worth 160 points, three independent 
Table 3. Most prevalent student comments included in the Nonstereotypes category: Nonstereotype (A) and Nonstereotypical Scientist (B) subcategories, including their frequencies and representative student quotes ${ }^{a}$

\begin{tabular}{|c|c|c|}
\hline Description & $n$ & Representative student quotes \\
\hline \multicolumn{3}{|l|}{ A. Nonstereotype } \\
\hline Any type of person & 9 & $\begin{array}{l}\text { "Anyone that is interested in learning and gaining knowledge can do science, it's not limited to any types } \\
\text { of people." } \\
\text { "While I believe anyone with enough hard work and perseverance can be competent in the field of science, } \\
\text { I do believe some people are naturally drawn to the subject." }\end{array}$ \\
\hline Good observers & 4 & $\begin{array}{l}\text { "The types of people that do science are innovative, observative }[s i c] \text { people." } \\
\text { "[Scientists] are hardworking, because they need to keep a close eye on experiments/observations." }\end{array}$ \\
\hline Analytical & 3 & $\begin{array}{l}\text { "[Scientists] are usually very logical thinkers who can figure things out on their own." } \\
\text { "[Scientists] are able to focus and think critically for long periods of time." }\end{array}$ \\
\hline Detail oriented & 3 & $\begin{array}{l}\text { "I think the people who do science have to be patient, detail-oriented." } \\
\text { "These people are ... very careful, detail-oriented individuals!" }\end{array}$ \\
\hline Good communicators & 2 & "The people who they do science ... can communicate to each other and share." \\
\hline Fact-based people & 2 & $\begin{array}{l}\text { "Scientists tend to be more fact-based people." } \\
\text { "People do science based on facts." }\end{array}$ \\
\hline Imaginative & 2 & "One scientist that comes to mind is Albert Einstein. He was very creative and imaginative." \\
\hline $\begin{array}{l}\text { Knowledgeable of } \\
\text { current events }\end{array}$ & 2 & $\begin{array}{l}\text { "[Scientists] typically are up to date w/all the news." } \\
\text { "These individuals have an interest in a field that's constantly changing so they probably are always learn- } \\
\text { ing to keep up with new information." }\end{array}$ \\
\hline Share ideas & 2 & $\begin{array}{l}\text { "[Scientists] like to share ideas to better understand themselves." } \\
\text { "The people who do science, they can communicate to each other and share." }\end{array}$ \\
\hline Go against stereotypes & 2 & $\begin{array}{l}\text { "I do somehow see a pattern, people expect successful scientist[s] to be male and expect them to have been } \\
\text { geniuses since they were in diapers. I, however, have recently notice[d] that a lot of women have been } \\
\text { important to science." } \\
\text { "[Albert Einstein] shows that you don't need to be a total bookworm to make an impact on the world" }\end{array}$ \\
\hline Enthusiastic & 2 & $\begin{array}{l}\text { "Bill Nye and Neil Degrasse Tyson are two great examples. They are always so excited and enthusiastic } \\
\text { about the universe and science as a whole." }\end{array}$ \\
\hline $\begin{array}{l}\text { Other nonstereotype } \\
\text { descriptions cited by } \\
\text { only one person each }\end{array}$ & 14 & $\begin{array}{l}\text { "Albert was an outdoorsy person." } \\
\text { "Scientist[s] always share one thing. A deep compassion." } \\
\text { "Science is something done ... within your body, mind, and soul." }\end{array}$ \\
\hline \multicolumn{3}{|c|}{ B. Nonstereotypical Scientist } \\
\hline Bill Nye & 5 & $\begin{array}{l}\text { "People like Bill Nye the Science Guy [do science]." } \\
\text { "Bill Nye and Neil Degrasse Tyson are two great examples." } \\
\text { "I don't know many scientists but I know Bill Nye." } \\
\text { "Bill Nye the Science Guy is the only real scientist I know." }\end{array}$ \\
\hline $\begin{array}{l}\text { Mention scientist family } \\
\text { member or friend }\end{array}$ & 2 & $\begin{array}{l}\text { "My ex-girlfriend is a marine biologist, and she would happily recount her day of paperwork testing and } \\
\text { more testing." } \\
\text { "I do not remember any exact names of scientists, but I know one friend who studies to be a doctor." }\end{array}$ \\
\hline Marie Curie & 2 & $\begin{array}{l}\text { "[Scientists] can be women (Marie Curie), or they can be dropouts (Albert Einstein)." } \\
\text { "The specific scientists that I know are Newton and Marie Curry [sic]." }\end{array}$ \\
\hline Nikola Tesla & 2 & $\begin{array}{l}\text { "Einstein, Edison, Tesla, Freud." } \\
\text { "Some examples would Leonardo Da-Vinci, Albert Einstein, Nikola Tesla, and Gauss." }\end{array}$ \\
\hline Thomas Armstrong & 2 & $\begin{array}{l}\text { "For example, Einstein ... did well doing science and also in fact, Thomas Armstrong." } \\
\text { "Thomas Armstrong talks about how the brain is like an ecosystem not a machine." }\end{array}$ \\
\hline Neil Degrasse Tyson & 2 & $\begin{array}{l}\text { "Neil Degrasse Tyson is an astrophysicist that studies the universe." } \\
\text { "Bill Nye and Neil Degrasse Tyson are two great examples because they are always so excited and enthusi- } \\
\text { astic about the universe and science as a whole." }\end{array}$ \\
\hline $\begin{array}{l}\text { Other nonstereotypical } \\
\text { scientists cited by } \\
\text { only one person each }\end{array}$ & 12 & $\begin{array}{l}\text { "I know Brian Greene, a physicist who rallies for string theory." } \\
\text { "I don't have anyone in mind, perhaps Jane Gooddall [sic] and Dana Nakase who loves marine biology." } \\
\text { "I know of ... the Mythbusters" }\end{array}$ \\
\hline
\end{tabular}

projects worth a combined 150 points, lab reports worth 215 points, and reading/reflection assignments worth 100 points. Four students who completed the survey on the second day of class dropped within the first $2 \mathrm{wk}$ and did not receive grades. Among the remaining 121 students, 90 (74\%) received a passing grade at the end of the course, while 20 $(17 \%)$ received a $\mathrm{W}$ (withdrawal) and $11(9 \%)$ received a " $\mathrm{D}$ " or an "F." Students earned an average grade point of 2.89 $(\mathrm{SD}=1.21)$.

Chi-square tests indicated that students identifying one or more Nonstereotype at the beginning of the class were more likely to pass the class than students who did not identify Nonstereotypes (87\% pass rate vs. $67 \%$ pass rate, respectively, $X=6.09, p=0.0136$; Figure 3A). Though failing to 
Table 4. Most prevalent student comments included in the Fields of Science category/subcategory, including their frequencies and representative student quotes

\begin{tabular}{|c|c|c|}
\hline Description & $n$ & Representative student quotes \\
\hline Doctors & 17 & $\begin{array}{l}\text { "I think that there are a ton of people that 'do science.' For example there are nurses, pharmacist, doctors." } \\
\text { "The types of people that do science are researchers, doctors." } \\
\text { "Types of people: doctors, nurses." }\end{array}$ \\
\hline Biologists & 16 & $\begin{array}{l}\text { "Biologist[s] study life in all its different forms." } \\
\text { "There are many different types of scientist ... scientist[s] from various fields like Biology..." }\end{array}$ \\
\hline Chemists & 14 & $\begin{array}{l}\text { "Chemists are involved with science." } \\
\text { "Scientist[s] can be people that not only study the human body like doctors ... but also chemists." }\end{array}$ \\
\hline Psychologists & 12 & $\begin{array}{l}\text { "Psychologists know what goes on in the brain and how it affects their actions." } \\
\text { "There are many types of scientist out there ... that study different things. For example, social science that } \\
\text { study human psychology." } \\
\text { "Psychologists 'do' science." }\end{array}$ \\
\hline Teachers & 9 & $\begin{array}{l}\text { "Researchers at universities including professors and grad students contribute to science." } \\
\text { "The types of people that do science are researchers, doctors ... teachers." }\end{array}$ \\
\hline Pharmacists & 7 & $\begin{array}{l}\text { "Scientist[s] can be people that not only study the human body..., but also ... pharmacists, etc." } \\
\text { "My sister is a pharmacist, and I consider her a scientist." }\end{array}$ \\
\hline $\begin{array}{l}\text { Other fields of science } \\
\text { cited by }<5 \% \text { of } \\
\text { respondents }\end{array}$ & 75 & $\begin{array}{l}\text { "Neurology-deals with neurology problems like epilepsy." } \\
\text { "People that do science are ... dentists." } \\
\text { "Another great example would be philosophers." } \\
\text { "NASA scientists use science to study space and the earth." }\end{array}$ \\
\hline
\end{tabular}

demonstrate strong statistical significance, Mann-Whitney tests suggested a similar trend, wherein students identifying one or more Nonstereotypes tended to receive higher grades (3.15 average grade point $[S D=1.02]$ vs. 2.72 average grade point [SD = 1.29], $Z=1.59, p=0.11$; Figure 3, B and C). In addition, students who identified one or more Nonstereotypical Scientists at the start of class received, on average, higher grades than those that did not (3.44 average grade point [SD $=0.81]$ vs. 2.78 average grade point $[S D=1.24]$, respectively, $Z=1.92, p=0.054$; Figure 4 , A and B). Evidence also suggests that students describing one or more Positive Stereotypes might have had higher pass rates than students who did not identify Positive Stereotypes (78\% vs. $64 \%$ pass rate, $X=2.75, p=0.097)$.

\section{DISCUSSION}

Because stereotypes and science identity have the potential to impact engagement, persistence, and success in STEM fields (see Introduction), a better understanding of the landscape of stereotypes among diverse groups of students could help inform efforts to increase participation in STEM. The current study sought to address gaps in the stereotypes literature by 1) piloting a survey of scientist stereotypes in a mostly nonwhite community college setting; 2) employing a survey using written and spoken responses, rather than a multiple-choice survey or drawings; 3) performing quantitative analyses to search for correlations between scientist stereotypes, student demographic characteristics, and success rates in a science course; and 4) comparing Mead and Metraux's (1957) scientist stereotypes with those identified by present-day students. In pursuit of these goals, we developed and tested a qualitative survey of stereotypes in a diverse, community college biology class. We examined the validity of the survey, finding that 1) students appeared to interpret the prompt appropriately, 2) reviewers could reliably code student responses into categories drawn from the literature, 3) such categories appeared to represent student intent regarding "positive" and "negative" comments, and 4) responses within the study population did not change significantly during a biology course in the absence of instruction related to stereotypes. Below we compare our results with trends uncovered regarding scientist stereotypes in prior studies.

\section{Positive Stereotypes of Scientists Were Common and Negative Stereotypes Were Rare}

Mirroring the results of other recent studies with different populations of students (e.g., Schneider, 2010; Wyer et al., 2010; Guy, 2013; Andersen et al., 2014), our survey found that positive images of scientists dominated the stereotypes reported by community college students (Table 2A). The most prevalent descriptions of scientists ("curious," "interested in work," "intelligent," "works to make world better," "passionate") were also very similar to the most prevalent descriptions found in other recent surveys (Wyer et al., 2010; Andersen et al., 2014). Our results additionally support the findings of Schneider (2010), in that the stereotypes reported by our mostly non-STEM major student population appear to relate mostly to professional competencies. Very few descriptions of scientists' social abilities arose in our survey.

Negative Stereotypes of scientists were very rare in our sample (Table 2B). Though not entirely unexpected with regard to other recent studies, we found the rarity of Negative Stereotypes in our sample striking. In some studies, non-STEM majors, women, and students from traditionally underserved racial backgrounds expressed comparatively negative attitudes, or at best neutral attitudes, toward science (Sundberg et al., 1994; Atwater et al., 1995; Weinburgh, 1995). Because student attitudes might inform stereotypes, and given that our sample included a large population of women, nonmajors, and students from races underserved in STEM, we anticipated that a larger number of negative images of scientists might appear in our sample compared with studies that 


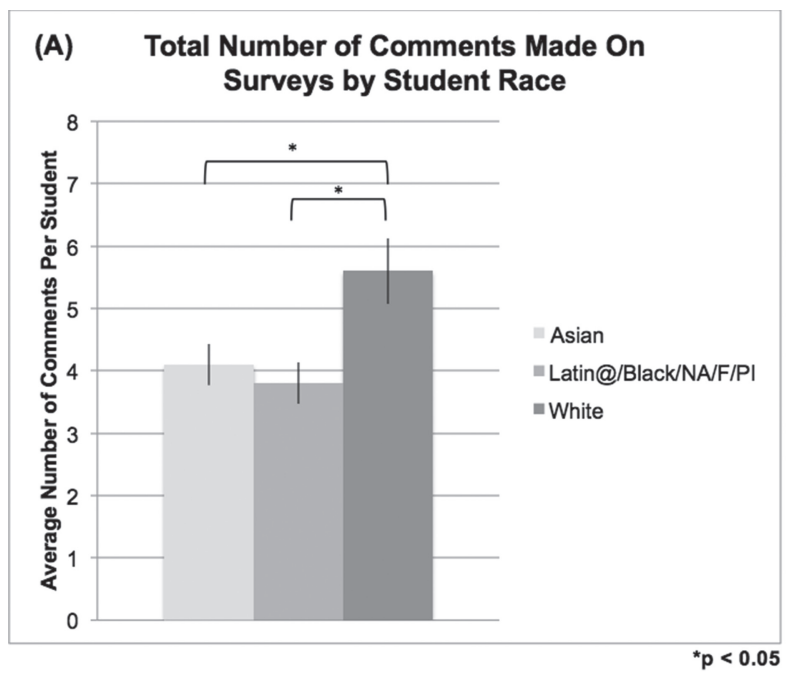

\section{(C) Percent of Comments that were Positive Stereotypes by Student Race}

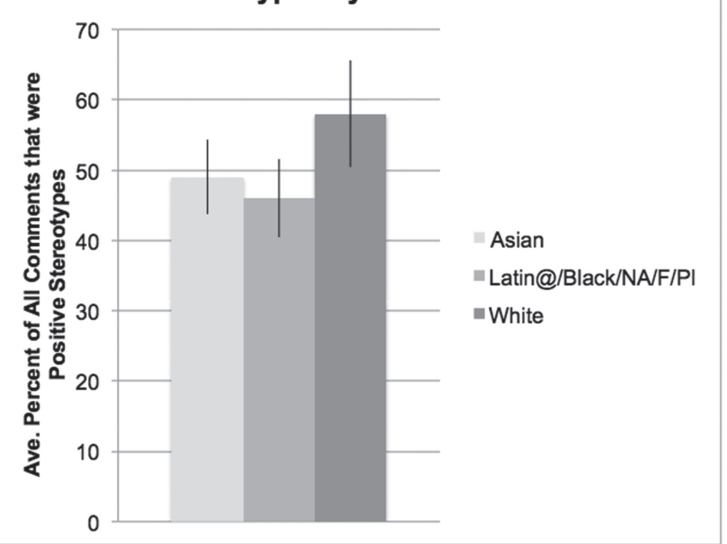

\section{(B) Percent of Comments that were Negative Stereotypes by Student Race}
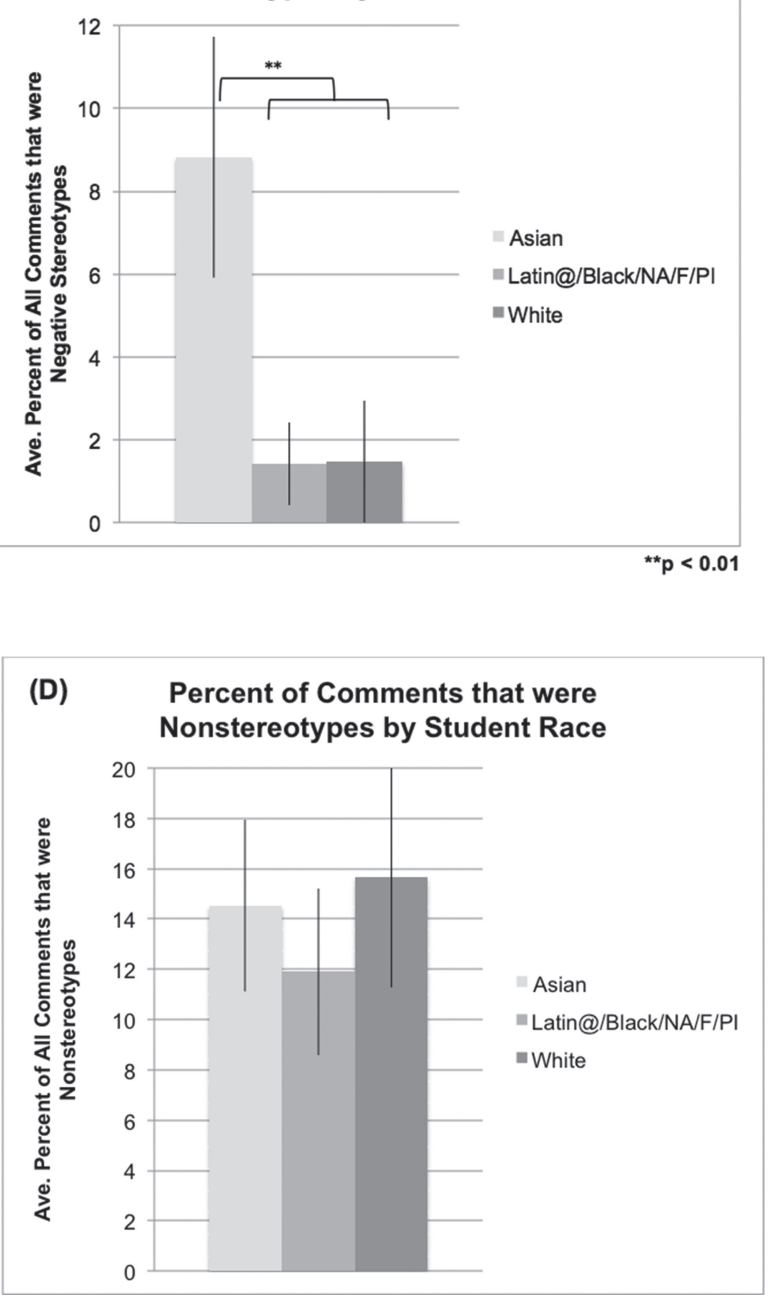

Figure 2. Total number of comments made by students in the survey (A) and relative number of Negative Stereotypes (B), Positive Stereotypes (C), and Nonstereotypes (D), disaggregated by student race. Latino/a, black, Native American, Filipino, Pacific Islander, Laotian, and Cambodian students grouped as underserved students. Error bars show \pm 1 SEM.

focused on STEM majors or predominantly white student populations.

Despite the fact that the instructor emphasized students' survey responses would not be graded and that there were no desirable right/wrong answers, we wondered whether some students might have held Negative Stereotypes but felt uncomfortable sharing them in writing during a biology class. We explored this possibility in follow-up telephone conversations with students, which occurred after the classes had completed. Ten of the students with whom we conversed had not indicated any Negative Stereotypes in their essay responses. As part of the discussions with those students, we mentioned the absence of some characteristics we had "expected to see more of," such as "always sitting in a lab," "introverted," or "nerdy." We then asked each student whether he/she was also surprised that those things did not make it out on his/her paper and whether he/she had any insights about why that might be. Two of the 10 students admitted to being surprised that ideas like those did not come out on paper, saying, for example, "I definitely thought things like that back then." This provides some evidence that, at least for some students, Negative Stereotypes existed but were not reported in the survey.

Seven of the remaining eight students, however, felt very strongly that they did not find negative descriptions like those relevant in describing scientists. One student explained, “That wouldn't have even crossed my mind. It's not even about what you might have ... this person might be more introverted ... this person might not be so detail oriented, but that's not really what matters. The interest [in the subject] is more overruling." Another student concurred, "That's not really a perspective I would take. ... Science is interesting. It's not like being a librarian or something. ... Science is something that requires a more dynamic personality."

The remaining student in this group expressed more complex sentiments regarding certain "negative" stereotypes. In 


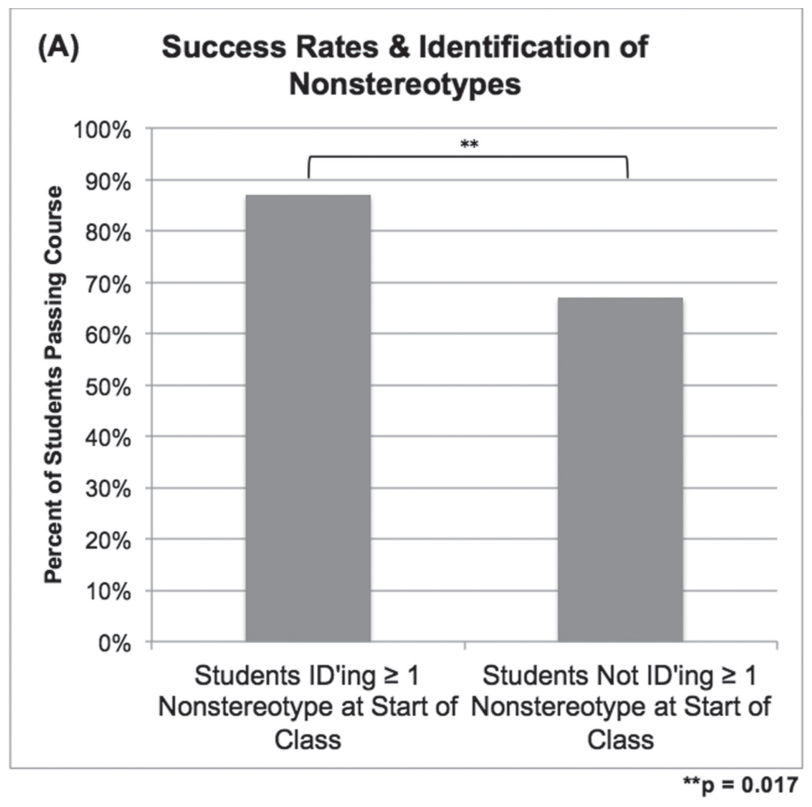

\section{(B) Average Course Grades \& Identification of Nonstereotypes}

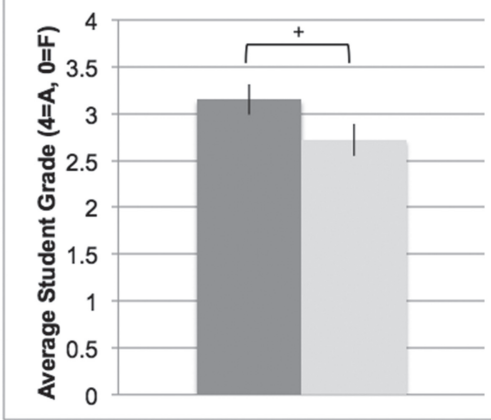

= Students ID'ing $\geq 1$ Nonstereotype at Start of Class

Students Not ID'ing $\geq 1$ Nonstereotype at Start of Class

\section{(C) \\ Distribution of Course Grades \& Identification of Nonstereotypes}

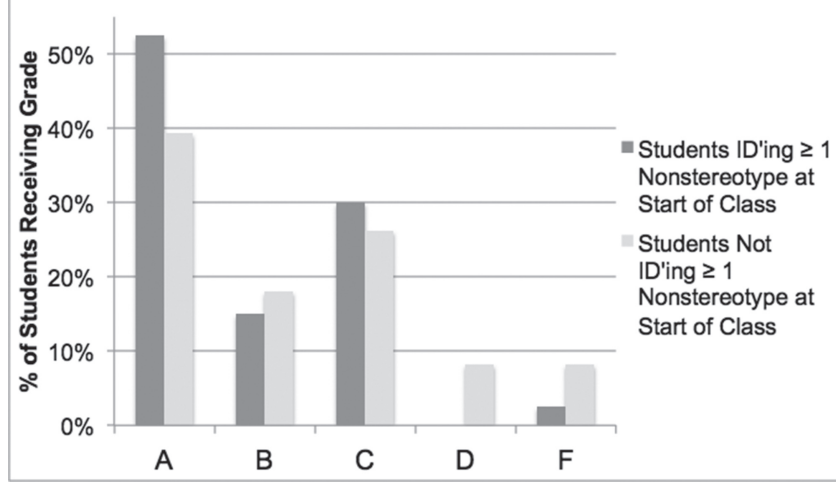

Figure 3. Success rates (A), levels of achievement (B), and distribution of grades (C) in Human Biology based on whether or not students identified Nonstereotypes of scientists at the start of class. Error bars show \pm 1 SEM.

\section{(A) Average Course Grade \& Identification of Nonstereotypical Scientists}

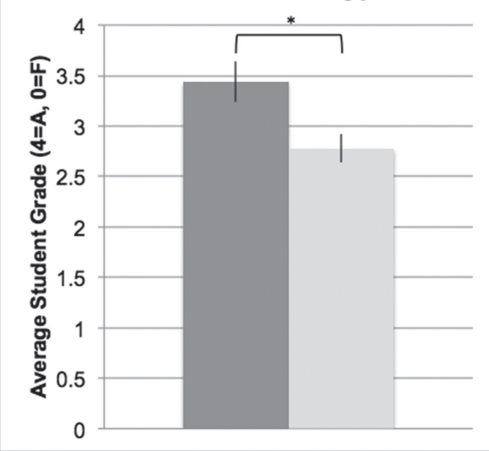

- Students ID'ing $\geq 1$ Nonstereotypical Scientist at Start of Class

Students Not ID'ing $\geq 1$ Nonstereotypical Scientist at Start of

Class

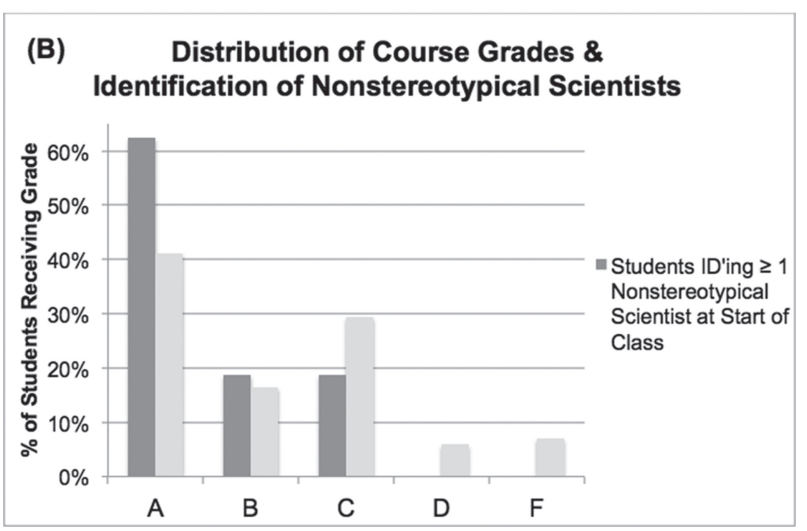

Figure 4. Levels of achievement (A) and distribution of grades (B) in Human Biology based on whether or not students cited Nonstereotypical Scientists at the start of class. Error bars show \pm 1 SEM.

explaining why those descriptors did not appear in her paper, she said, "I know that those words can have a negative connotation and I don't think it's insulting to be called a nerd. I think that being smart or being. ... I think it's great. I think it's good to be a nerd or a geek or anything, but I don't think that maybe that positive connotation is widespread." This was the only example of a student explicitly redefining a "negative" stereotype in positive terms, and it appears that she had decided not to list those descriptions in her survey for fear of having them misinterpreted.

While it appears that Negative Stereotypes might be underrepresented to some extent in our data due to some students desire to avoid stating unfavorable descriptions of scientists in class, evidence from interviews would suggest that such situations might not have been highly prevalent. Rather, the high frequency of Positive Stereotypes in our sample appears to be representative of the types of stereotypes actually held by students. This, and the results of other recent studies showing similar trends (e.g., Schneider, 2010; Wyer et al., 2010; Guy, 2013; Andersen et al., 2014), may reflect a broader national trend in attitudes regarding scientists. A 2002 National Science Foundation survey found that relatively few individuals held negative views of scientists (National Science Board, 2002). 
It is also interesting that, in the current study, these positive images of scientists occurred even in the absence of concrete reference points for who scientists really are (see following section of Discussion on examples of scientists). In this sense, students in the current study might be similar to those in Andersen et al. (2014), who were characterized as potentially biased toward being overly idealistic about science.

Though Negative Stereotypes were scarce in our sample overall, the Negative Stereotypes we did observe were almost entirely confined within students identifying as Asian (Figure $2 \mathrm{~B}$ ). Data from telephone conversations contributed to this trend in an unexpected way. Earlier in this Discussion, we noted that only two of the students with whom we spoke felt they held Negative Stereotypes but had not recorded them on their papers. One of those students identified as Asian, and the other identified as Filipina/Pacific Islander (an AAPI ethnicity disaggregated in this study). On the other hand, all the black, Latino/a, and white students with whom we spoke felt very strongly that Negative Stereotypes had not mistakenly or intentionally been left out of their papers.

This concentration of observed Negative Stereotypes among Asian students was striking, since AAPI individuals are often portrayed as being "overrepresented" in STEM (Lewis et al., 2009). It would be easy to assume that students from races that have traditionally been marginalized in STEM fields would harbor more "negative" images of science and scientists. However, such a trend was not observed in our sample, and indeed attitudes toward science among students from underserved backgrounds are often positive (Oakes, 1990). Very few studies have examined AAPI students in relation to STEM, likely due to the stereotype of Asians as "model minority" students who perform well in math and science and therefore do not warrant attention in regard to diversifying STEM (Maramba, 2013). However, this stereotype masks the fact that the term "Asian" includes at least 48 ethnic groups, many of which are underserved in STEM (Maramba, 2013). Contrary to the model minority stereotype, some students within the Asian category demonstrate comparatively low senses of belonging and academic integration in college (Orsuwan, 2011). Asians, therefore, include a wide range of ethnic groups, many of which are underserved in STEM, and may not have homogeneously positive attitudes regarding science and scientists.

While additional sampling and conversations with students will be necessary to better understand our results, these findings provide additional evidence that issues of equity and diversity among AAPI students and STEM deserve further attention from researchers, policy makers, and college faculty and staff. Because "the largest sectors of AAPI college students are concentrated in community colleges" (Maramba, 2013, p. 159), community colleges will represent an important venue for such future work. One of the most pressing needs in future studies in AAPI-serving institutions will be disaggregation of the term "Asian" to uncover trends among the nearly 50 highly varied ethnicities that typically fall under that designation.

\section{Students Cited Very Few Examples of Actual Scientists}

Though the essay prompt asked students to refer to specific scientists, only approximately one-third of students named or explicitly described a specific individual they were thinking of when they were writing about the types of people who do science. Evidence from phone conversations suggested this was because many students simply lacked knowledge of any scientists. Only six of the 13 individuals we talked with by telephone indicated they had a specific scientist in mind while writing to the survey prompt. The remaining seven students either indicated they "didn't know of any scientists," only knew of some "friends that were interested in science," or drew upon fictional popular culture references in determining what types of people do science (e.g., "That's the idea I got mostly from movies"). This would appear to support Schneider's (2010) assertion that non-STEM majors tend to have few concrete reference points for constructing scientist stereotypes. Schneider (2010) further suggests this lack of familiarity with scientists could explain non-STEM majors' low opinions of scientists' social competencies compared with STEM majors.

\section{Correlations between Certain Images of Scientists and Student Success/Achievement}

Previous studies found that agreement with Positive Stereotypes predicted performance in science (Krajkovich and Smith, 1982) and career choices in STEM (Beardslee and O'Dowd, 1961; Wyer, 2003; Schneider, 2010). While the current study uncovered trends suggesting Positive Stereotypes correlate with success in Human Biology, such trends did not reach the level of statistical significance $(p=0.097)$.

We did, however, uncover statistically significant correlations between students recording Nonstereotypes and success in a biology class (Figures 3 and 4). The most common of these Nonstereotypes was "any type of person" does science. In other words, it appears students who described images of scientists that went beyond traditional stereotypes more often passed and received higher grades in the course. Other factors, like levels of self-efficacy and sense of belonging, might correlate with the holding of Nonstereotypes, and those other factors might have more directly caused the enhanced performance we observed (Trujillo and Tanner, 2014). It should also be noted that grades are an indirect measure of achievement and sometimes reflect more about a student's ability to navigate the school environment than they do about a student's learning (Schinske and Tanner, 2014). However, our findings could generate interest in testing interventions aimed at broadening students' images of scientists and evaluating whether those interventions impact success in STEM courses.

\section{Observed Stereotypes Differ from Those Highlighted in Recent Quantitative Surveys}

As noted in the Introduction, the two most recently developed quantitative surveys of scientist stereotypes-the ISSS (Krajkovich and Smith, 1982) and the SOS (Wyer et al., 2010) - are partially based on stereotypes set forth in qualitative data published in the 1950s (Mead and Metraux, 1957). This raises questions regarding whether the stereotypes highlighted in those surveys still resonate with students in the 21st century. Some of the stereotypes featured in the ISSS and SOS are indeed very similar to those uncovered in the present study (e.g., "especially intelligent," "highly 
focused," "logical"). However, other stereotypes in the quantitative surveys bear little or no resemblance to stereotypes observed in our population (e.g., "have unhappy marriages," "are careful with expensive instruments," "have fun with colleagues at work," "learn to use new equipment quickly"). Though our results do not represent the full range of stereotypes held by all students, the fact that a number of items in the quantitative instruments lacked parallels in our data suggests these surveys might benefit from updated information regarding stereotypes. Updated qualitative data on stereotypes, like those provided here, could assist in ensuring that stereotypes highlighted in future quantitative surveys are more relevant to present-day students.

In addition, prior studies using existing surveys of scientist stereotypes have focused mainly on the importance of positive and negative stereotypes in predicting interest, persistence, and success in STEM (see the Introduction). However, because our work used a qualitative approach that did not limit responses to a preset list of stereotypes, we were able to detect correlations between Nonstereotypes and these student outcomes. If the goal of the quantitative surveys of stereotypes is to provide information relevant to persistence and success in STEM, our results suggest it could be fruitful to add items that assess students' agreement with descriptions of scientists that fall outside traditional stereotypes and convey very diverse images of the scientist. We predict that agreement with such items might correlate even more strongly with persistence and success in STEM than positive stereotypes.

\section{Limitations}

As with other studies based on qualitative data, our conclusions might not be appropriately generalizable for drawing conclusions regarding stereotypes across a broader population (Schneider, 2010). Because, as in prior studies (Chambers, 1983; Catsambis, 1995; Rubin et al., 2003), the current work uncovered differences in types of stereotypes between demographic groups of students, performing additional qualitative and quantitative surveys in diverse settings has the potential to reveal novel stereotypes and different proportions of types of stereotypes than observed here. Additionally, though we encouraged students to think deeply and include details, our survey did not require students to write a certain number of words or share a certain number of descriptions of scientists. It was up to each student to decide how much to share in his/her response. Therefore, our data cannot be thought of as an exhaustive list of every scientist stereotype held by students in our sample. Our survey was better suited to detect the most prominent or most relevant stereotypes in students' minds at the time of the survey.

Because the current study relied on written responses (and, to a lesser extent, oral responses) in the English language, our methodology might have been biased in ways that oversampled stereotypes among students with the most English speaking and writing experience and might have failed to fully capture stereotypes from language learners or students with less English writing experience and self-efficacy. This was of particular concern for us, given that only $31 \%$ of surveyed students spoke English as their first language. Though we attempted to minimize these biases by providing sufficient time for all students to think and write, our data provide evidence indicating that biases might have been present. Namely, white students and students' for whom English was their first language recorded more comments in response to our survey than did nonwhite students and language learners. It is possible this represented an authentic signal indicating that nonwhite students and language learners had fewer images of scientists upon which they could draw, but this conclusion is difficult to separate from the likely impacts of language and writing barriers some students might have experienced during the survey. To partially account for this possible oversampling of certain students' ideas, we converted continuous data (numbers of stereotypes reported) to nominal data (presence or absence of types of stereotypes) and percentages (percent Positive Stereotypes of all comments).

\section{Future Directions}

Given that responses to this qualitative survey can be reliably and relatively quickly coded and then analyzed quantitatively, this survey might be useful in a variety of contexts. This survey could be combined with additional qualitative prompts and provided alongside quantitative surveys to create a more powerful mixed-methods approach to measuring stereotypes. The researcher could provide the qualitative survey to students first and then follow up with a quantitative survey such as the SOS (Wyer et al., 2010). This would allow researchers to explore the range of stereotypes and detect unexpected descriptions, while at the same time evaluating students' ideas regarding the fixed set of descriptors in the quantitative survey. This mirrors some implementations of the DAST, though applying our essay prompt in lieu of the DAST would evade some of the well-documented issues surrounding interpretations of DAST drawings (Symington and Spurling, 1990; Thomas et al., 2006).

It would additionally be of interest in this context to test interventions aimed at modifying students' stereotypes. The finding that expressing Nonstereotypes correlated with higher success rates in a biology class may particularly motivate the testing of interventions. Interactions with peers and teachers has been shown to influence stereotypes (Colbeck et al., 2001; Izumi and Hammonds, 2007), which suggests that classroom interventions could prove effective in modifying stereotypes that might otherwise contribute to stereotype threat. Schneider (2010) further notes that, if students lack knowledge of specific scientists to inform their images of scientists-as appears to be the case for our students-interventions that introduce those students to scientists could represent powerful tools for shifting their stereotypes of scientists. Indeed, some studies have suggested that the introduction of role models from diverse backgrounds has the potential to shift stereotypes and enhance self-efficacy (Bohrmann and Akerson, 2001; McIntyre et al., 2004). Other interventions that have the potential to impact students' stereotypes or mitigate stereotype threat include values affirmations (Cohen et al., 2006; Miyake et al., 2010), explicit instruction regarding stereotype threat (Johns et al., 2005), and metacognitive exercises (Miele, 2014).

Indeed, our essay prompt appears suitable for applying a quasi-experimental approach to evaluating such interventions. We presented evidence that the numbers and types of stereotypes in a population of students remain relatively 
stable throughout a biology course. Thus, if an intervention were applied in a similar course with a similar population of students and bookended with our qualitative survey, changes in students' stereotypes could be more easily attributed to the intervention as opposed to other factors. In such an experiment, it would be helpful to also collect evidence regarding students' majors, levels of interest in science, and attitudes toward studying science to search for possible changes in intent to pursue STEM in conjunction with shifts in stereotypes.

Finally, since community colleges occupy a key position in terms of addressing STEM equity gaps (Wang, 2013), particularly in relation to Latino/a, black, and AAPI students, we hope that the current study motivates additional work on stereotypes and science identity in diverse community college settings.

\section{ACKNOWLEDGMENTS}

We extend our sincere appreciation to Mary Wyer, Kimberly Tanner, Gloriana Trujillo, and the monitoring editor and anonymous reviewers for their valuable feedback regarding this article. We also thank the De Anza College President's Office, especially President Brian Murphy and Executive Assistant Tina Woo, for generously providing M.C. and J.K. with travel funds to present preliminary data from this project at the 2014 SABER national meeting. J.S. thanks Mallory Newell, Mark Healy, and De Anza's IMPACT AAPI program for support and advice and Ann and Neal Schinske for their continual encouragement.

\section{REFERENCES}

American Association of Community Colleges (2014). American Association of Community Colleges Fact Sheet. www.aacc.nche .edu/AboutCC/Documents/FactSheet_2014_bw_r2.pdf (accessed 18 December 2014).

Andersen HM, Krogh LB, Lykkegaard E (2014). Identity matching to scientists: differences that make a difference? Res Sci Educ 44, 439-460.

Astin AW, Astin HS (1992). Undergraduate Science Education: The Impact of Different College Environments on the Educational Pipeline in the Sciences, Final Report. Los Angeles: Higher Education Research Institute, Graduate School of Education, University of California, Los Angeles.

Atwater MM, Wiggins J, Gardner CM (1995). A study of urban middle school students with high and low attitudes toward science. J Res Sci Teach 32, 665-677.

Beardslee DC, O'Dowd DD (1961). The college-student image of the scientist: Scientists are seen as intelligent and hard-working but also as uncultured and not interested in people. Science 133, 9971001.

Bickman L, Rog D (2009). The SAGE Handbook of Applied Social Research Methods, Thousand Oaks, CA: Sage.

Bohrmann M, Akerson VL (2001). A teacher's reflections on her actions to improve her female students' self-efficacy toward science. J Elementary Sci Educ 13, 241-55.

Brickhouse NW, Lowery P, Schultz K (2000). What kind of a girl does science? The construction of school science identities. J Res Sci Teach $37,441-458$.

Carlone HB (2004). The cultural production of science in reform-based physics: girls' access, participation, and resistance. J Res Sci Teach 41,392-414.

Catsambis S (1995). Gender, race, ethnicity, and science education in the middle grades. J Res Sci Teach 32, 243-257.
Chambers DW (1983). Stereotypic images of the scientist: the Draw-A-Scientist Test. Sci Educ 67, 255-265.

Cohen GL, Garcia J, Apfel N, Master A (2006). Reducing the racial achievement gap: a social-psychological intervention. Science 313, 1307-1310.

Colbeck CL, Cabrera AF, Terenzini PT (2001). Learning professional confidence: linking teaching practices, students' self-perceptions, and gender. Rev High Educ 24, 173-191.

Dikmenli M (2010). Undergraduate biology students' representations of science and the scientist. College Student J 44, 579-588.

Dix LS (1987). Minorities: Their Underrepresentation and Career Differentials in Science and Engineering: Proceedings of a Workshop, Washington, DC: National Academies. http://books.google .com/books?hl = en\&lr $=$ \&id $=$ C04rAAAAYAAJ\&oi $=$ fnd \&pg $=$ PA $1 \& \mathrm{dq}=$ dix + scientist + role + models\&ots $=4 \mathrm{Ft} 2 \mathrm{OxP7QL \& sig}$ $=$ oOXKbxjmoCE0aJtZ7A6ODpzGxFA (accessed 18 December 2014).

Erb TO, Smith WS (1984). Validation of the attitude toward women in science scale for early adolescents. J Res Sci Teach 21, 391-397.

Finson KD (2002). Drawing a scientist: what we do and do not know after fifty years of drawings. School Sci Math 102, 335-345.

Frechtling J (2002). The 2002 User-Friendly Handbook for Project Evaluation, Washington, DC: National Science Foundation. http:/ / eric.ed.gov/?id = ED468812 (accessed 18 December 2014).

Gee JP (2000). Identity as an analytic lens for research in education. Rev Res Educ 25, 99-125.

Guy BS (2013). Persistence of African American men in science: exploring the influence of scientist identity, mentoring, and campus climate. PhD thesis, North Carolina State University, Raleigh. http://gradworks.umi.com/35/75/3575625.html.

Hamilton DL, Sherman JW (1994). Stereotypes. Handbook of Social Cognition, vol. 2, Hillsdale, NJ: Lawrence Erlbaum, 1-68.

Izumi Y, Hammonds F (2007). Changing ethnic/racial stereotypes: the roles of individuals and groups. Soc Behavior Personal 35, 845852.

Johns M, Schmader T, Martens A (2005). Knowing is half the battle: teaching stereotype threat as a means of improving women's math performance. Psychol Sci 16, 175-179.

Krajkovich JG, Smith JK (1982). The development of the image of science and scientists scale. J Res Sci Teach 19, 39-44.

Lewis JL, Menzies H, Nájera EI, Page RN (2009). Rethinking trends in minority participation in the sciences. Sci Educ 93, 961-977.

Maramba DC (2013). Creating successful pathways for Asian Americans and Pacific Islander community college students (AAPIs) in STEM. In: Community Colleges and STEM: Examining Underrepresented Racial and Ethnic Minorities, New York: Routledge, 156-171.

McIntyre RB, Lord CG, Gresky DM, Frye GDJ, Bond CF Jr. (2004). A social impact trend in the effects of role models on alleviating women's mathematics stereotype threat. Curr Res Soc Psychol 10, 116-136.

Mead M, Metraux R (1957). Image of the scientist among highschool students. Science 126, 384-390.

Miele E (2014). Using the Draw-A-Scientist Test for inquiry and evaluation. J Coll Sci Teach 43, 36-40.

Miyake A, Kost-Smith LE, Finkelstein ND, Pollock SJ, Cohen GL, Ito TA (2010). Reducing the gender achievement gap in college science: a classroom study of values affirmation. Science 330, 1234-1237.

National Academy of Sciences, National Academy of Engineering, and Institute of Medicine (2011). Expanding Underrepresented Minority Participation: America's Science and Technology Talent at the Crossroads, Washington, DC: National Academies Press.

National Science Board (2002). Science and Technology: Public Attitudes and Public Understanding. Science and Engineering 
Indicators, Washington, DC: National Science Foundation. www .nsf.gov/statistics/seind02/c7/c7h.htm (accessed 18 December 2014).

Oakes J (1990). Opportunities, achievement, and choice: women and minority students in science and mathematics. Rev Res Educ $16,153-222$

Orsuwan M (2011). Interaction between community college processes and Asian American and Pacific Islander subgroups. Community Coll J Res Practice 35, 743-755.

Oxford English Dictionary (2014). Definition of "stereotype" in English, Oxford, UK: Oxford University Press. http://www.oxforddictionaries .com/us/definition/american_english/stereotype (accessed 16 September 2014).

Rosenthal DB (1993). Images of scientists: a comparison of biology and liberal studies majors. School Sci Math 93, 212-216.

Rubin E, Bar V, Cohen A (2003). The images of scientists and science among Hebrew-and Arabic-speaking pre-service teachers in Israel. Int J Sci Educ 25, 821-846.

Ryder-Burge A (2011). Understanding how women's and minorities' perceptions of scientists influence students' choice of major Master's thesis, North Carolina State University, Raleigh. http:// repository.lib.ncsu.edu/ir/handle/1840.16/6612 (accessed 18 December 2014).

Sax LJ (2001). Undergraduate science majors: gender differences in who goes to graduate school. Rev High Educ 24, 153-172.

Schinske JN, Tanner KD (2014). Teaching more by grading less (or differently). CBE Life Sci Educ 13, 159-166.

Schneider JS (2010). Impact of undergraduates' stereotypes of scientists on their intentions to pursue a career in science. PhD thesis, North Carolina State University, Raleigh. http://repository.lib .ncsu.edu/ir/handle/1840.16/6184 (accessed 18 December 2014).

Seymour E, Hewitt N (1997). Talking about Leaving: Why Undergraduates Leave the Sciences, Boulder, CO: Westview.

Steele CM (1997). A threat in the air: how stereotypes shape intellectual identity and performance. Am Psychol 52, 613.
Sumrall WJ (1995). Reasons for the perceived images of scientists by race and gender of students in grades $1-7$. School Sci Math 95 , 83-90.

Sundberg MD, Dini ML, Li E (1994). Decreasing course content improves student comprehension of science and attitudes towards science in freshman biology. J Res Sci Teach 31, 679-693.

Symington D, Spurling H (1990). The "Draw-A-Scientist Test": interpreting the data. Res Sci Technol Educ 8, 75-77.

Tai RH, Sadler PM, Loehr JF (2006). Factors influencing success in introductory science. In: Handbook of College Science Teaching, Arlington, VA: NSTA Press, 359-368.

Thomas MD, Henley TB, Snell CM (2006). The Draw-A-Scientist Test: a different population and a somewhat different story. Coll Student J 40, 140.

Trujillo G, Tanner KD (2014). Considering the role of affect in learning: monitoring students' self-efficacy, sense of belonging, and science identity. CBE Life Sci Educ 13, 6-15.

Wang X (2013). Community colleges and underrepresented racial and ethnic minorities in STEM education: a national picture. In: Community Colleges and STEM: Examining Underrepresented Racial and Ethnic Minorities, New York: Routledge, 3-16.

Weinburgh M (1995). Gender differences in student attitudes toward science: a meta-analysis of the literature from 1970 to 1991. J Res Sci Teach 32, 387-398.

Wyer M (2003). Intending to stay: images of scientists, attitudes toward women, and gender as influences on persistence among science and engineering majors. J Women Minor Sci Eng 9(1). Www .dl.begellhouse.com/journals / 00551c876cc2f027,588fd13a4ac98f 5d,0772b1b83ebd7818.html (accessed 18 December 2014).

Wyer M, Schneider J, Nassar-McMillan S, Oliver-Hoyo M (2010). Capturing stereotypes: developing a scale to explore US college students' images of science and scientists. Int J Gender Sci Technol 2(3). http://genderandset.open.ac.uk/index.php/genderandset/ article/viewArticle/78 (accessed 18 December 2014). 